\title{
Risk Assessment of Riparian Plant Invasions into Protected Areas
}

\author{
LLEWELLYN C. FOXCROFT,${ }^{*} \uparrow \ddagger^{* *}$ MATHIEU ROUGET, $§$ AND DAVID M. RICHARDSON $\dagger$ \\ *Institute for Plant Conservation, Botany Department, University of Cape Town, Rondebosch 7701, South Africa \\ †Centre for Invasion Biology, Department of Botany and Zoology, Stellenbosch University, Private Bag X1, Matieland 7602, \\ South Africa \\ ¥Savanna Ecosystem Research Unit, South African National Parks, Private Bag X 402, Skukuza 1350, South Africa \\ $\S$ Biodiversity Planning Unit, South African National Biodiversity Institute, Private Bag X101, Pretoria 0001, South Africa
}

\begin{abstract}
Protected areas are becoming increasingly isolated. River corridors represent crucial links to the surrounding landscape but are also major conduits for invasion of alien species. We developed a framework to assess the risk that alien plants in watersheds adjacent to a protected area will invade the protected area along rivers. The framework combines species- and landscape-level approaches and has five key components: (1) definition of the geographical area of interest, (2) delineation of the domain into ecologically meaningful zones, (3) identification of the appropriate landscape units, (4) categorization of alien species and mapping of their distribution and abundance, and (5) definition of management options. The framework guides the determination of species distribution and abundance through successive, easily followed steps, providing the means for the assessment of areas of concern. We applied the framework to Kruger National Park (KNP) in South Africa. We recorded 231 invasive alien plant species (of which 79 were major invaders) in the domain. The KNP is facing increasing pressure from alien species in the upper regions of the drainage areas of neighboring watersheds. On the basis of the climatic modeling, we showed that most major riparian invaders have the ability to spread across the KNP should they be transported down the rivers. With this information, KNP managers can identify areas for proactive intervention, monitoring, and resource allocation. Even for a very large protected area such as the KNP, sustainable management of biodiversity will depend beavily on the response of land managers upstream managing alien plants. We suggest that this framework is applicable to plants and other passively dispersed species that invade protected areas situated at the end of a drainage basin.
\end{abstract}

Keywords: biological invasions, Kruger National Park, landscape ecology, propagule pressure, risk analysis, spatial analysis, species-distribution modeling

Evaluación del Riesgo de Invasiones de Plantas Ribereñas Áreas Protegidas

Resumen: Las áreas protegidas están cada vez más aisladas. Los corredores ribereños constituyen enlaces vitales en el paisaje circundante pero también son el principal conducto para la invasión de especies exóticas. Desarrollamos un marco de referencia para evaluar el riesgo de que plantas exóticas en cuencas bidrológicas adyacentes a un área protegida la invadan a lo largo de los ríos. El marco combina métodos a nivel de especies y de paisaje y tiene cinco componentes clave: (1) definición de un área geográfica de interés, (2) delineación del dominio en zonas ecológicamente significativas, (3) identificación de las unidades paisajísticas apropiadas, (4) clasificación de especies exóticas y mapeo de si distribución y abundancia, y (5) definición de opciones de manejo. El marco conduce la determinación de la distribución y abundancia de especies a través de pasos sucesivos, fácilmente seguidos, y proporciona medios para la evaluación de áreas de interés. Aplicamos el marco al Parque Nacional Kruger (PNK) en África del Sur. Registramos 231 especies de plantas exóticas invasoras ( 79 de las cuales eran invasoras mayores) en el dominio. El PNK está enfrentando mayor presión de

\footnotetext{
**email llewellynf@sanparks.org

Paper submitted June 15, 2006; revised manuscript accepted September 7, 2006.
}

412 
especies exóticas en las regiones altas de las áreas de influencia de cuencas bidrológicas aledañas. Con base en modelos climáticos, mostramos que la mayoría de los principales invasores ribereños tienen la capacidad de dispersarse por el PNK si fueran transportados por los ríos. Con esta información, los administradores del PNK pueden identificar áreas para acciones preventivas, monitoreo y asignación de recursos. Aun para un área protegida tan extensa como el PNK, el manejo sustentable de la biodiversidad dependerá en gran medida de los administradores de tierras en la cuenca alta y su manejo de plantas invasoras. Sugerimos que este marco de referencia es aplicable a plantas y otras especies de dispersión pasiva que invaden áreas protegidas situadas al final de una cuenca bidrológica.

Palabras Clave: análisis de riesgo, análisis espacial, ecología del paisaje, invasiones biológicas, modelos de distribución de especies, Parque Nacional Kruger, presión de propágulos

\section{Introduction}

Protected areas are becoming increasingly isolated, forming islands of relatively intact ecosystems in a matrix of land uses that are often incompatible with biodiversity conservation. The degree to which activities outside protected areas affect the functioning of ecosystems within such areas depends on the geography of the region and numerous socioeconomic factors (Pollard et al. 2003). Protected areas are connected with their surroundings in many ways. Besides the many edge effects that involve the spillover of human-related activities across the boundaries of protected areas (see references in Alston \& Richardson 2006), there are also other important ways humans affect protected areas. Roads and rivers are particularly important conduits for the spread of invasive species (Pyšek \& Prach 1994) and form links between the protected areas and their surroundings; such links are both beneficial and problematical. Roads allow access for management activities but create openings for the introduction of unwanted organisms (e.g., Lonsdale \& Lane 1994; Gelbard \& Harrison 2003). Rivers provide corridors and are conveyor belts for the movement of organisms between isolated protected areas (van Wilgen et al. 2006). Protected areas are usually too small to contain entire watersheds, but they are linked to surrounding areas via rivers (van Wilgen et al.). This linkage adds a level of complexity to the management of protected areas.

Where alien plant species are abundant in the watersheds surrounding a protected area this may provide a continuous source of propagules, greatly complicating long-term control efforts. For example, in South Africa's Kruger National Park (KNP), some of the worst invasive plant species spread into the park along major rivers (Foxcroft \& Richardson 2003). Given the complex mosaic of land uses and the abundance and diversity of invasive alien plant species in the watersheds drained by the major rivers that flow through the KNP (Fig. 1a), further incursions of alien species along rivers are a major threat to the biodiversity conservation objectives for the park (KNP 2006).
The KNP objectives hierarchy (KNP 2006) guides management policy and strategy. Nevertheless, physical control interventions are currently mostly ad hoc in the absence of a framework to guide actions. Management projects are currently underway to address the invasion of alien species through a number of vectors. For example, management of plants arising from the spread of ornamental plants in tourist villages (Foxcroft 2001) is a major focus of control efforts. Aquatic weeds such as water hyacinth (Eichbornia crassipes [Mart.] Solms.) and water lettuce (Pistia stratiotes L.) are treated with biological control agents and herbicides. The largest control efforts in the KNP have been aimed at managing the invasive cactus, sour prickly pear (Opuntia stricta [Haworth] Haworth.), which has invaded more than 80,000 ha (Foxcroft et al. 2004), and at continuous follow-up control against a suite of invasive riparian species by the national Working for Water program (Foxcroft \& Richardson 2003; Freitag-Ronaldson \& Foxcroft 2003).

Nevertheless, the management of invasive plant species in riparian zones is increasingly seen as a futile task because operations are not planned with due cognizance of the configuration of the KNP in relation to propagule sources outside the park. There is an urgent need to assess priorities for management of species that have potential for introduction to the park along rivers. Rivers are a particularly important component of the KNP because the entire southern (Crocodile River) and northern (Levuvhu and Limpopo rivers) boundaries and parts of the western boundary (Sabie and Nsikazi rivers) are formed by rivers. Even more important, seven major rivers flow through the park from drainage areas severely invaded by numerous alien species (Fig. 1a \& 1b).

Although qualitative risk-assessment protocols (e.g., Tucker \& Richardson 1995; Pheloung et al. 1999; Daehler \& Carino 2000) are useful for preventing or reducing introductions of unwanted species, the challenges associated with managing a suite of species already in a particular area are immense. Risk-assessment protocols usually aim to identify potentially invasive species on the basis of broad criteria (e.g., previous invasion history) at a 


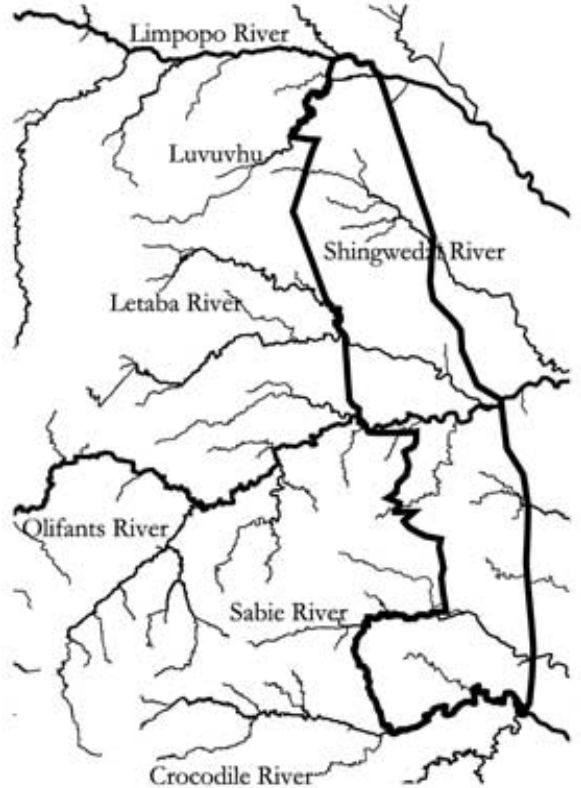

a

口Kruger National Park

Major rivers flowing through the KNP

Nertiary Rivers

Secondary Rivers

$\mathcal{N}$ Major Rivers
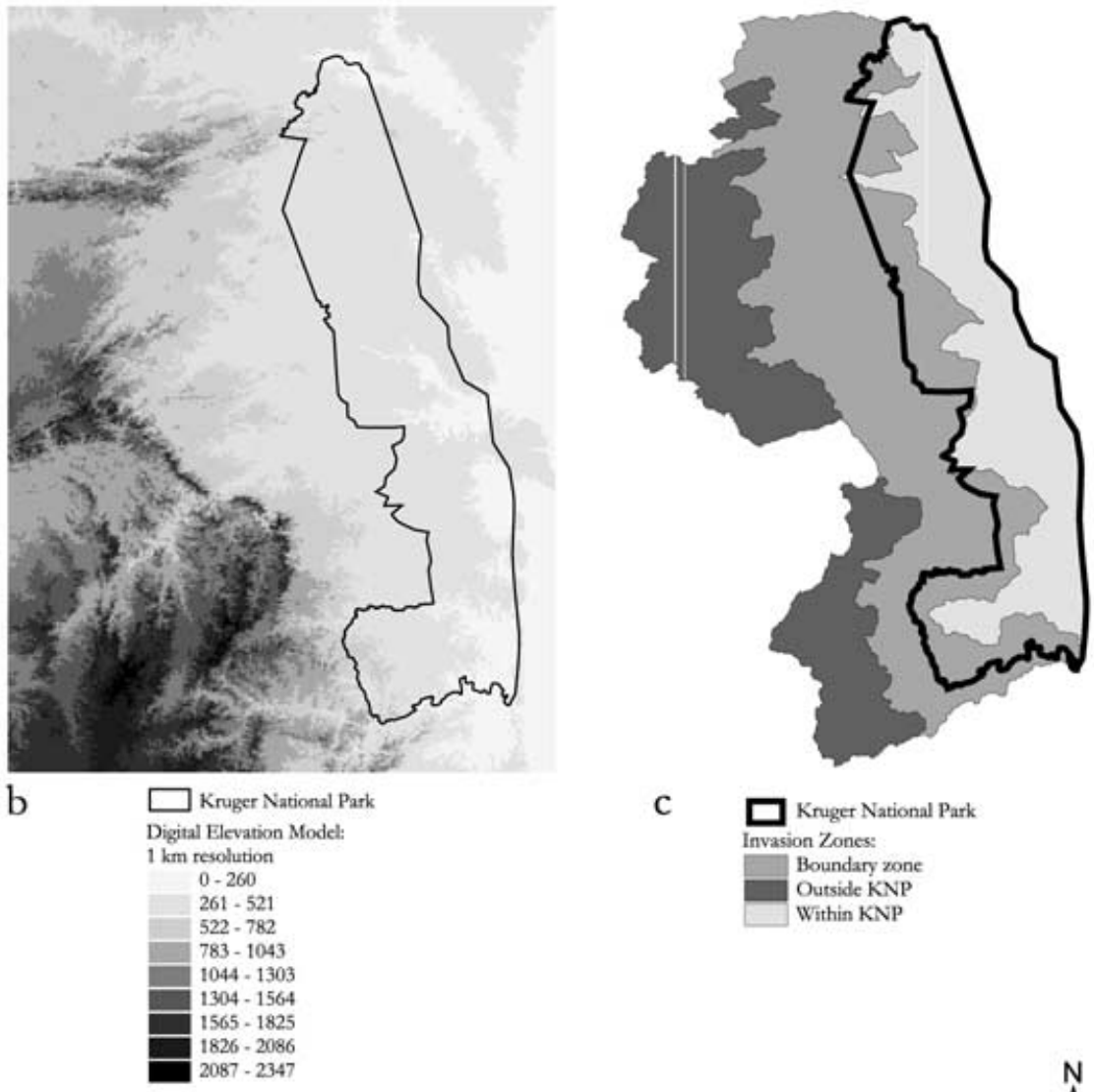

C
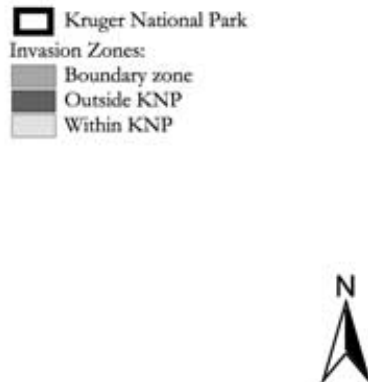

Figure 1. Kruger National Park (KNP): (a) the major rivers flowing west to east through KNP; (b) topography of the area showing the higher-elevation areas to the west of KNP; and (c) domain (the entire area, including the protected area and surrounding watersheds) divided into three zones for assessing the risk of plant invasion into KNP.

regional scale, with some modification for particular areas (Daehler \& Carino 2000). An objective assessment of the risk of spread from different watersheds would help managers identify areas where proactive intervention would be most effective and where monitoring for new incursions would be most effective.

We developed a framework to assess the risk that alien plants in watersheds adjacent to a protected area will invade the protected area along rivers. We applied the framework to the KNP situation and discuss how its application could improve conservation management and planning.

\section{Methods}

\section{Risk-Assessment Framework}

Although qualitative risk assessment is useful at a broad scale, we required a framework for use at a local scale that would provide insights into key species and areas. For the framework to provide a robust assessment of the risk that alien species will invade a protected area from surrounding watersheds, we believed that it had to be specific to the local geography; consider species of special concern (i.e., species known to be aggressive invaders in particular habitats in the area); include abundance or, as a proxy, species richness as a method of incorporating propagule pressure; and be relevant and useful to the management goals of the protected area.

Figure 2 outlines the generic framework we developed that can be applied to other areas in similar situations. The framework contains five components:

1. Define the geographical area of interest (i.e., the domain-the entire area including the protected area and surrounding watersheds). The domain includes both the primary area of interest (the protected area) and a much larger surrounding area, including the upstream drainage basins that act as potential sources of invasive alien species. The shape of the protected area within the broader landscape matrix should be considered to ensure adequate inclusion of the areas that may act as sources of propagules. 


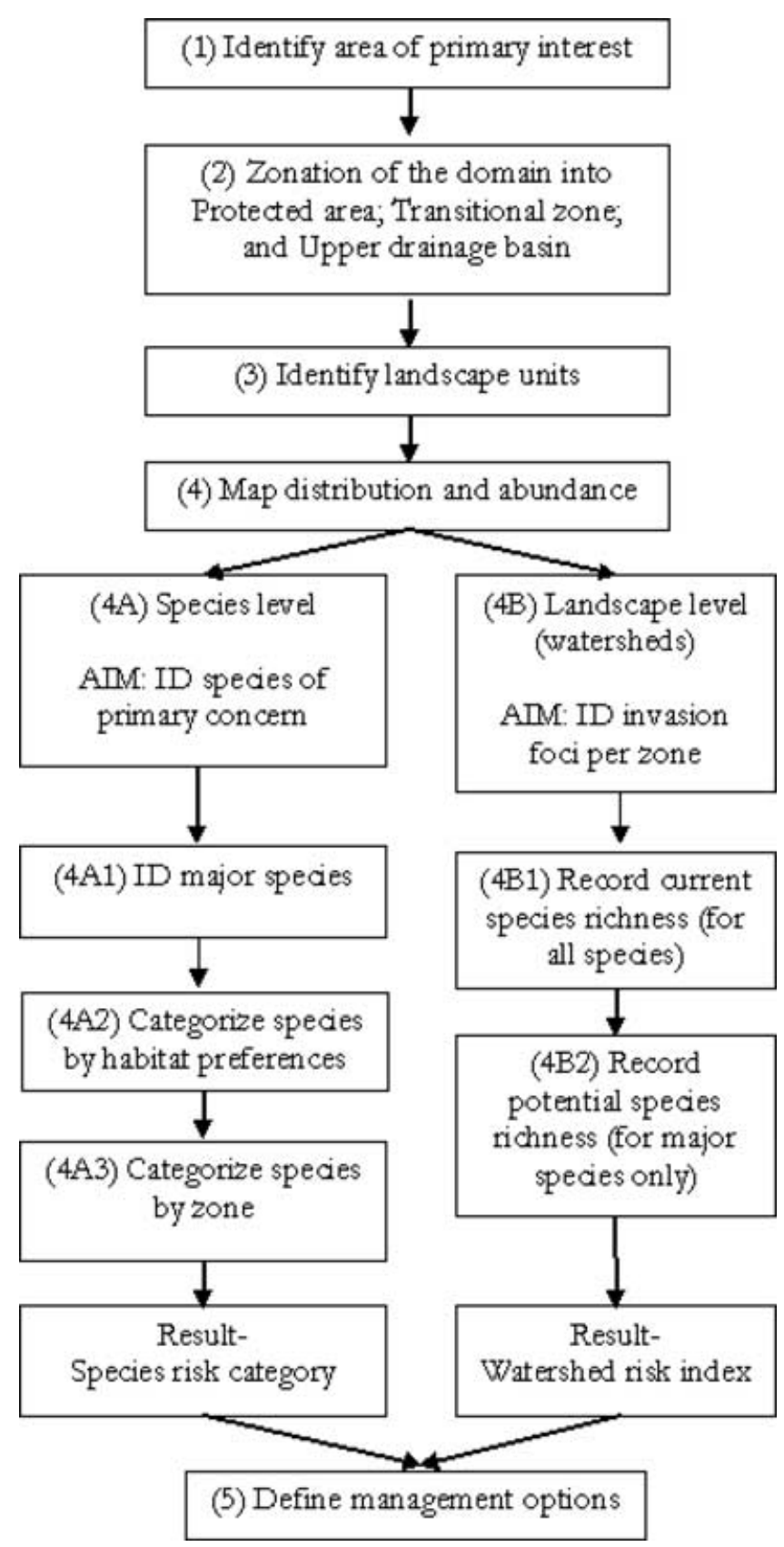

Figure 2. A framework for assessing the risk of alien plant invasion into a protected area that combines species- and landscape-level considerations.

2. Delineate the domain into zones that are ecologically meaningful and relevant to management so that areas with a high risk of invasion can be identified. We used a zone within the protected area, a transitional zone, and a zone encompassing the remainder of the domain. The transitional zone provided an area for monitoring and implementing early warning or eradication systems because alien plants move passively down the watershed, through the transitional zone, and ultimately into the protected area.
3. Identify the appropriate landscape units at which to explore the richness of alien species based on criteria such as the availability and resolution of data and usefulness of the data to management. The landscape unit selected should be appropriate for studying distinct river systems and allow evaluation and assessment of potential risks posed by certain areas. Depending on the size of the protected area, the rest of the domain, and resources available to management, the landscape units selected may be coarser for larger areas and finer in the smaller areas because the smaller areas can be more intensively monitored.

4. Map the distribution and abundance of alien species. For many areas detailed floristic data are available. Where data need to be collected, a number of techniques are available (e.g., Henderson 1998, 1999, 2001). The resolution of the data should be appropriate to the scale of the landscape unit selected.

Most approaches for determining species spread and risk focus attention separately on single species (e.g., focus on specific species and identify and manage all known populations) or particular areas (e.g., manage a suite of species in a specially demarcated area to minimize impact) (DoC 2000). Our aim, to determine overall management options based on the spatial arrangement of species of primary concern and the invasion foci, called for a combination of these two approaches (species and landscape [watershed] levels).

a. In the species-level section of the framework, identify species of primary concern and their distribution. Because certain species are considered more serious invaders than others (e.g., chromolaena, Chromolaena odorata [L.] R.M. King \& H. Rob., in the KNP context), the presence of one or a few of these requires specific and targeted management action.

(i) Identify major invader species (i.e., widespread alien plant species or invaders that occur in dense stands). Identification of a subset of major invaders forces managers to consider these species explicitly in formulating management recommendations. This can be done in many ways-for example, by analysis of abundance or expert opinion-but requires that a manageable number of species that are most likely to cause harmful impacts on biodiversity are listed for priority actions.

(ii) Categorize species by habitat preference. Separate alien species into habitat preference categories (i.e., alien plants that predominantly occur in riparian, landscape, or both riparian and landscape areas) to focus on those species most likely to be passively dispersed by river flows and floods. We also separated the most widespread and localized species and placed these in a matrix to determine the species risk 
categories. From this, appropriate management intervention, such as early detection, eradication, or biological control, is determined.

(iii) Categorize species by zone. Separate the species into the three zones determined in component 2 to assess the species that occur in the protected area, adjacent to it, or in the upper basin of the protected area.

b. Assess sources of propagule pressure outside the protected area and map areas of high invasion risk within the protected areas.

(i) Record current alien species richness. Determine the current species richness (for all recorded alien species) per landscape unit (watershed) and per zone. Species richness is used to provide a measure of the availability and size of the propagule pool and is used as a proxy for species abundance data, which is often unavailable.

(ii) Record potential alien species richness. To account for future risks consider the current distribution of alien plants in the landscape units and predicted species distribution of the major invaders. Various approaches are now available for predicting species distributions (e.g., Thuiller 2003; Guisan \& Thuiller 2005). The potential species distribution is useful because including species likely to be present in the future extends the lifespan of the framework in terms of its relevance to managers in the medium term (5-10 years). Furthermore, because the predicted distribution of the major species "fills in" or supplements the data, databases for invasive species are frequently incomplete due to the rapidly changing nature of invasions.

5. Define management options. In the final step assess both the species' risk category and the watershed risk index. The species risk category assesses the threat that specifically selected species pose to the protected area based on their distribution and proximity to the protected area. The watershed risk index delineates the threat posed by the current (and predicted) pools of high propagule supply and the proximity of the threat to the protected area. The species risk category and the watershed risk index provide an understanding of the combined effects of the number and species of alien invaders. Species are categorized into manageable groups and suitable management recommendations are provided per group.

\section{Case Study of Kruger National Park}

We used KNP as a case study through which to evaluate the framework. The discussion is arranged numerically to correspond with the numbered components above and in Fig. 2.
1. Kruger National Park covers $20,000 \mathrm{~km}^{2}$ in the northeastern corner of South Africa. Its entire eastern boundary borders on Mozambique. It extends 360 $\mathrm{km}$ north to south and $90 \mathrm{~km}$ east to west at its widest point. Located in the midreaches of an extensive drainage basin that arises in the higher-elevation areas to the west (Fig. 1b), KNP is composed of mostly gently undulating landscapes (Gertenbach 1983). Elevation in the domain (i.e., the entire area including the protected area and surrounding watersheds) varies from $2253 \mathrm{~m}$ asl (Table 1) in the west to $104 \mathrm{~m}$ asl in KNP. Our study area includes KNP within the broader landscape context. The landscape contains quaternary watersheds up to approximately $140 \mathrm{~km}$ west of KNP boundary. Of the seven main river systems, KNP managers have jurisdiction over only a small proportion of each. The Crocodile River, which is $316 \mathrm{~km}$ long, has only $36 \%$ under formal protection in KNP. The Letaba ( $481 \mathrm{~km}, 26 \%$ protected formally), Limpopo (736, 4\%), Luvuvhu (225 km, 35\%), Olifants (704 km, 14\%), Sabie $(178,57 \%)$, and Shingwedzi $(159 \mathrm{~km}, 63 \%)$ are protected in KNP. We were interested in only the upstream basin because alien plants enter KNP through dispersal of propagules in water. We did not consider areas downstream of KNP in Mozambique because there is no evidence to suggest that alien plants disperse passively upstream into KNP.

Riparian aliens are primarily introduced into KNP through dispersal of propagules along rivers. Thus, it may be argued that the simplest framework for controlling riparian alien plants from spreading into the park would be to focus simply on rivers that have the highest runoff rates. To ascertain that the species richness in the watersheds was not correlated simply to water runoff, we carried out linear regression to determine whether we could predict species richness as a function of mean annual runoff.

2. On the basis of the elevation and broad biophysical criteria (moisture and vegetation gradients), we determined three zones to evaluate the proximity and potential risk of each of the zones to KNP, (1) within the protected area $(\mathrm{KNP})$, where the watershed is contained completely within KNP, (2) in the transitional zone, where the KNP boundary falls within the particular watershed, and (3) in the upper drainage basin, representing the uppermost watersheds in the river system, bounded by the top of the tertiary watershed. In some cases we adjusted the zones slightly to make the zone more continuous along the length of KNP boundary (Fig. 2c).

3. Owing to the large area covered, we worked at the scale of quaternary watersheds (quaternary catchments are nested subdivisions within primary, secondary, and tertiary catchments). Quaternary catchments are used for regional-scale planning for many environmental initiatives in South Africa, such as the 
Table 1. Environmental and land-use variables used to characterize the watersheds in Kruger National Park (KNP), including a summary of 20 features for the overall domain (the entire area, including the protected area and surrounding watersheds) and each of the three alien-plant management zones.

\begin{tabular}{|c|c|c|c|c|}
\hline \multicolumn{5}{|l|}{ Alien plant species richness } \\
\hline all alien species & 231 & 192 & 165 & 97 \\
\hline riparian invaders & 185 & 153 & 138 & 88 \\
\hline \multicolumn{5}{|l|}{ River length } \\
\hline total length of all segments $(\mathrm{km})$ & 7437 & 2158 & 3559 & 1720 \\
\hline $\operatorname{area}\left(\mathrm{km}^{2}\right)$ & 52,169 & 14,259 & 25,771 & 12,139 \\
\hline ave. watershed size $\left(\mathrm{km}^{2}\right)$ & 462 & 264 & 572 & 551 \\
\hline size of largest watershed $\left(\mathrm{km}^{2}\right)$ & 1249 & 759 & 1249 & 927 \\
\hline size of smallest watershed $\left(\mathrm{km}^{2}\right)$ & 47 & 47 & 254 & 182 \\
\hline ave. mean annual runoff $(\mathrm{mm})$ & 21 & 39 & 17 & 6 \\
\hline \multicolumn{5}{|l|}{ Primary land-use types } \\
\hline plantations (\%) & 6 & 19 & 1 & 0.00 \\
\hline urban (\%) & 2 & 3 & 2 & 0.03 \\
\hline water bodies (\%) & 0.1 & 0.2 & 0.1 & 0.05 \\
\hline \multicolumn{5}{|l|}{ Topography } \\
\hline mean elevation ( $\mathrm{m}$ asl) & 561 & 892 & 468 & 323 \\
\hline max. elevation (m asl) & 2253 & 2253 & 1501 & 700 \\
\hline min. elevation (m asl) & 104 & 419 & 122 & 104 \\
\hline
\end{tabular}

Working for Water (invasive alien plant control program). Our study area contained 121 quaternary watersheds, ranging in size from $1249 \mathrm{~km}^{2}$ to $47 \mathrm{~km}^{2}$. We thought the quaternary watersheds would provide an appropriate scale against which to determine the species richness. This was based on the size of the entire domain and the resolution of the data. Furthermore, because we were interested in the potential of alien species to invade down the major rivers into KNP, we thought the watershed approach would provide the appropriate landscape unit for this study.

4. Data on the current distribution of invasive alien plants in the domain were taken from the Southern African Plant Invaders Atlas (SAPIA; Henderson 1998, 1999, 2001). The SAPIA database has more than 50,000 georeferenced records based on a quarter-degree gridsquare system $\left(15^{\prime}\right.$ latitude $\times 15^{\prime}$ longitude), representing roughly $25 \times 27 \mathrm{~km}$. Although relatively coarse, the SAPIA data are the best available alien plant distribution data for southern Africa (Richardson et al. 2005). The data were collected over many years, with a number of participants, and data collection is ongoing. In addition, because we were assessing alien plant distribution at a large scale (i.e., the watershed), we thought these data would be appropriate for this purpose (see Nel et al. 2004 for a discussion on this data set). We rescaled the current distribution of species to quaternary watersheds. Coverages for quarter-degree squares (QDS) and watersheds were overlaid in a geographic information system (GIS), and we listed all species currently occurring in each watershed by overlapping species distribution from SAPIA at the QDS scale and watershed boundaries.

a. (i) We selected records of species considered to be major invaders as defined by Nel et al. (2004). These were widespread alien plant species or invaders that occur in dense stands. We decided to focus on the major invaders for the purposes of predicting the potential distribution of "transformer species" (terminology following Richardson et al. 2000).

(ii) Alien plants were categorized into riparian or landscape species depending on the type of habitat they invade. We considered species riparian or landscape if more than $75 \%$ of their records from SAPIA fell into the respective category. If $<75 \%$, then we designated the species an invader of both riparian and landscape habitats. We were primarily interested in "riparian" and "riparian and landscape" invaders, given that our focus was on species with propagules that can be dispersed along rivers. We considered landscape invaders if they had a high probability of invading up the catena into the drier upland areas, once having established along the riparian zones. 
Table 2. Species richness of major invaders (i.e., widespread alien plant species or invaders that occur in dense stands) for each of the three alien plant management zones in Kruger National Park (KNP).

\begin{tabular}{llcc}
\hline & & \multicolumn{2}{c}{ KNP presence $^{b}$} \\
\cline { 3 - 4 } Zone & Distribution $^{a}$ & yes & no \\
\hline${\text { Within } \mathrm{KNP}^{c}}$ & localized & 41 & - \\
& widespread & 5 & - \\
Transition $^{d}$ & localized & 25 & 17 \\
& widespread & 17 & 0 \\
Upper basin $^{e}$ & localized & 25 & 17 \\
& widespread & 18 & 5 \\
\hline
\end{tabular}

${ }^{a}$ Localized if the species occurred in $<50 \%$ of the watersheds within the particular zone.

${ }^{b}$ The number of species recorded in the KNP according to Foxcroft et al. (2003).

${ }^{c}$ Zone included within the KNP.

${ }^{d}$ Zone where the KNP boundary falls within the particular watershed.

${ }^{e}$ Uppermost watersheds in the river system bounded by the top of the tertiary watershed.

(iii) For each zone we summed the number of watersheds that the major species occurred in based on the current species distribution (Table 2). For species already in the KNP, we used the KNP alien plant list (Foxcroft et al. 2003) as the best available plant list.

b. (i) We used the number of invasive alien species (species richness) in the watersheds to quantify the potential risk that each watershed poses to the lower river reaches. The best measure for this would be the abundance of species in the watersheds, but we did not have these data available. Our rationale was that the higher the alien species richness in a watershed, the more likely the watershed could act as a source of propagules to initiate an invasion downstream.

(ii) We assessed the number of watersheds each major invader could potentially invade. Assessing the potential distribution of invasive species can be problematic because invasive species are seldom in equilibrium with the environment (Rouget et al. 2004; Jimenez-Valverde \& Lobo 2006). Nevertheless, climatic-envelope modeling provides a useful tool to assess potential distribution of a species. We rescaled the potential distribution of species to quaternary watersheds. Using existing models for predicting the potential distribution of invasive plants in South Africa (Rouget et al. 2004), we determined the potential distribution of the 79 major invaders with a variant of climaticenvelope models (CEMs) on the basis of the Mahalanobis distance. To further explain and determine the potential distribution of the species in the watersheds, we derived potential species rich- ness for all alien species. This was done by determining whether a potential invader could invade a given watershed. After evaluating the distribution maps for a number of species, we decided to use a $10 \%$ rule to determine whether the species would fall into a particular watershed. Where the species was observed to potentially invade $\geq 10 \%$ of the area of the watershed, the species was recorded as present in that watershed (Rouget et al. 2004). We were then able to assess potential species richness per watershed and the number of watersheds invaded by each species.

\section{Results}

\section{Species Risk Category}

We recorded 231 species in the domain: 191 species in the upper basin, 165 in the transitional zone, and 97 in KNP. Seventy-nine species were major invaders. Seventy-two, 66, and 45 species occurred in each zone, respectively.

Within KNP (Table 2) most species were still localized (e.g., giant reed [Arundo donax L.] and bugweed [Solanum mauritianum Scop.]), and a small number were widespread (e.g., lantana [Lantana camara L.] and castor-oil plant [Ricinus communis L.]). Of the 79 major invasive species, 46 occurred in KNP. In the transition zone only 17 species were not recorded in KNP (e.g., black wattle [Acacia mearnsii De Wild.]), whereas 42 species were present. A similar pattern held for the upper basin, with only 22 species not yet in KNP and 43 species present in KNP.

\section{Watershed Risk Index}

The high species richness in the upper basin (192 species) represented a substantial source of invasion for KNP (Fig. $3 a)$. The invasion of the upper basin and transitional zone appeared to be substantially worse than in KNP, but with pathways of spread linking these areas with KNP (Fig. $3 a-3 c)$. There are two main pathways of spread into KNP. In the central part of the domain the Letaba and Olifants river systems provide the links, and in the southern parts the links are provided by the Sabie and Crocodile rivers. In the northern part of the domain, the link between the upper catchments and KNP via the Levuvhu and Limpopo rivers appears to form a less important conduit (Fig. 3b and 3c). City and town development, commercial plantation forestry, and the associated transformation of natural vegetation appear to have taken place later in comparison with the more-developed southern region. In addition, the region through which the Limpopo and Levuvhu rivers flow is more arid than farther south; thus, the invasion is still at an early stage and less pronounced. Nevertheless, the distribution of major riparian weeds (Fig. 3c) along the corridor suggests that some species have the 
a) all invasive species

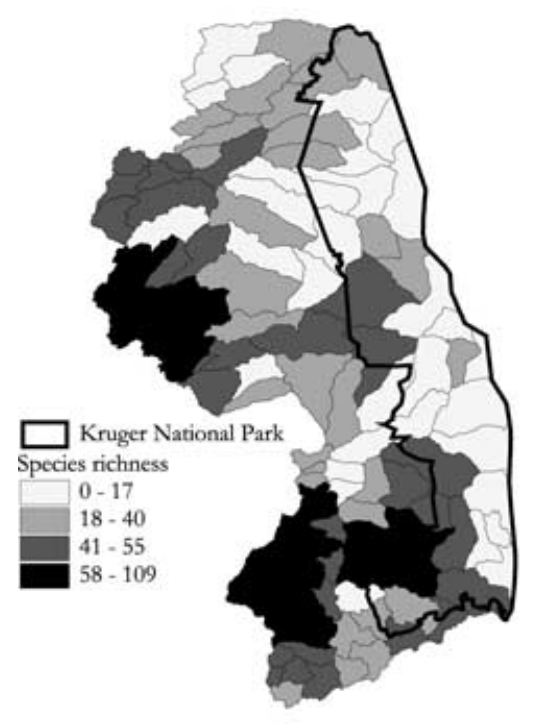

c) major riparian invaders

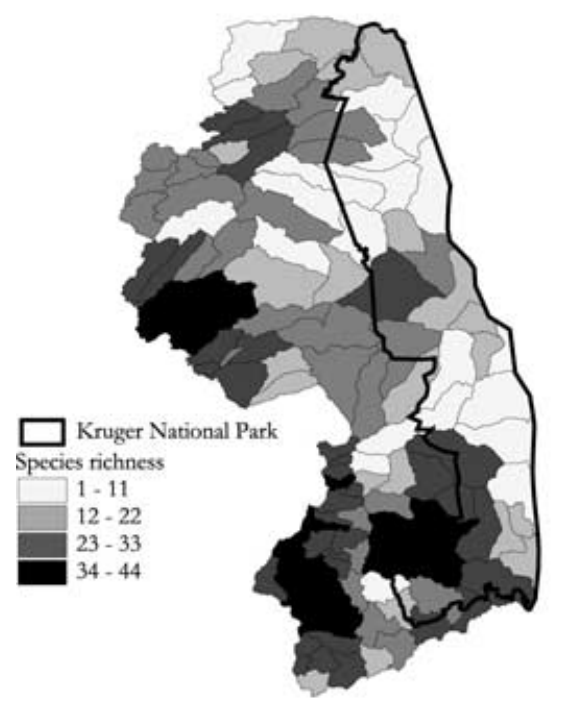

100

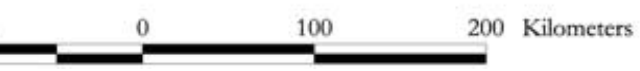

b) all riparian invaders

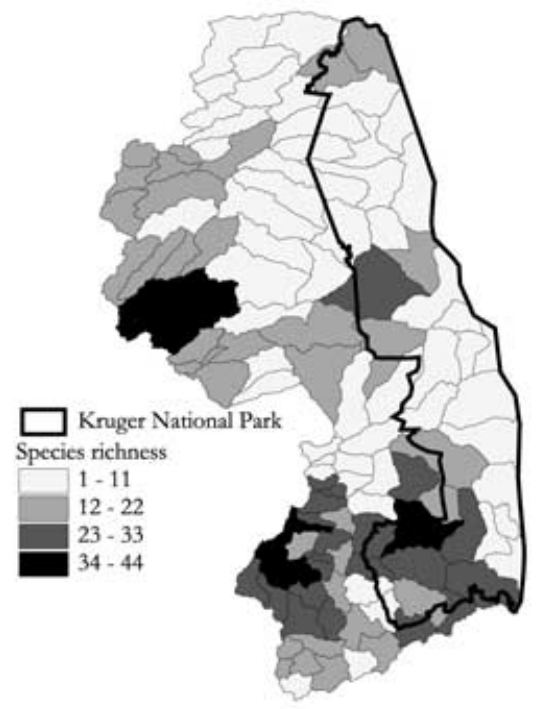

d) major riparian invaders (predicted)

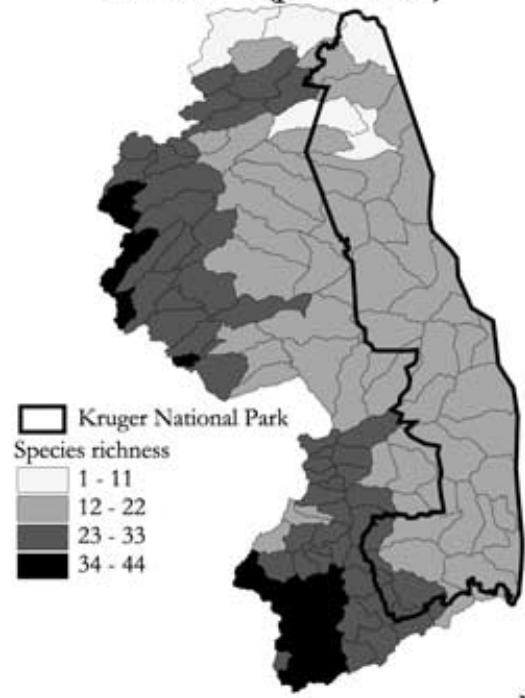

A
Figure 3. Potential risk of donating alien species (watershed risk index) that each watershed poses to the lower river reaches based on species richness of (a) all invasive alien species (based on 231 species), (b) riparian invasive alien species (based on 185 species), (c) major riparian species (based on 55 species), and (d) predicted distribution of major riparian species (based on 79 species, i.e., widespread alien plant species or invaders that occur in dense stands). ability to overcome these potentially limiting barriers and become just as important in linking KNP to the upper basin. This distribution also places the likely source for propagules closer to KNP. The predicted species distribution map (Fig. 3d) indicates the ability of major riparian species to spread across KNP should they be transported down the rivers.

In the linear regression between mean annual runoff and species richness, riparian species richness and mean annual runoff were significantly $(\mathrm{P}=5.045 \mathrm{e}-008)$, but weakly, correlated (multiple $R^{2}=0.2217$ ). Therefore, although there was a significant relationship, the relatively weak correlation cannot simply be used as a predictor of plant invasion along rivers for management purposes.

On the basis of our assessment, the following management recommendations can be made. Species localized in the upper basin and transitional zone, but are not yet present in KNP, should be targeted for eradication. This includes, for example, pom pom weed (Campuloclinium macrocephalum [Less.] DC.), inkberry (Cestrum laevigatum Schlehtd), and pepper tree (Schinus molle L). Species widespread in the upper zone and only occurring occasionally in the transition zone and not yet recorded in KNP, such as black wattle, should be eradicated in KNP, 
contained where it occurs in the transitional zone, and managed at acceptable levels in the upper zone.

Within KNP, widespread species, such as lantana and castor-oil plant, should be managed at tolerable levels. Localized species such as parthenium (Parthenium bysterphorous $\mathrm{L}$.) and giant reed must at minimum be contained in their present sites and eradicated where feasible. Management action will depend mainly on the area of the invasion of the specific species. Chromolaena might also be considered in this context, but the species-level assessment of the framework categorizes chromolaena as a major invader, warranting species-specific targeted action.

\section{Discussion}

Protected areas are influenced substantially by threats beyond their borders, and traditional management strategies are usually ineffective. The complicated land-use pattern and enormity of problems surrounding protected areas result in plans that are unsustainable and inefficient in the long term. Some management plans for invasive species focus on one or a few species considered particularly threatening, neglecting a suite of other species and the fact that controlled species are likely to be replaced by other alien plants. The framework we propose provides an objective tool for overcoming these problems. It organizes the evaluation of both species and areas of concern and provides managers with objectively defined priorities. This is a first assessment and should be followed up periodically as management progresses through the control operations to determine changes in species' distribution and abundance. The whole process requires ongoing monitoring and adaptation to changing conditions, as is currently applied in KNP's strategic adaptive management process (Freitag-Ronaldson \& Foxcroft 2003).

Applying the framework to KNP illustrated its benefits. $\mathrm{KNP}$ is a very large conservation area (one of the largest in Africa). Nonetheless the topography, land use, and abundance of invasive plant species outside the park make it essential to consider areas upstream from the park when formulating long-term management plans. Although it is accepted that there were many alien plant species surrounding the park and that these pose a threat to biodiversity conservation, no detailed evaluation of management priorities in areas surrounding KNP has been made. Management activities have focused only on dealing with species currently perceived as serious invaders. A small buffer zone adjacent to the KNP has been included in some management operations in the past-this being the only example of working beyond KNP boundaries. This focus is inadequate because the threats posed by the distribution of alien plant species in the broader watershed areas are not considered. The transition zone requires sub- stantially more attention to lessen the effects of future invasions. For example, 17 species not yet recorded in KNP are still localized and should be targeted for management. Twenty-two invasive species that occur in the upper basin are not yet present in KNP. Seventeen of these 22 are localized, and all efforts should be made by the provincial authorities to target these species.

River corridors provide links between the heavily invaded upper basin and the largely uninvaded lower reaches of the watershed. These corridors facilitate the spread of invasive species throughout KNP and warrant targeted and specific action. The riparian areas are also reasonably well delineated, requiring only a narrow zone parallel to the river to be considered in clearing efforts, providing species have not yet moved into the broader landscape. Nevertheless, where the plants have already spread into the broader landscape, the assessment of plant distribution in the quaternary watershed provides good management unit boundaries for plant-control operations.

What does the framework provide beyond traditional approaches to invasive species management? First, the framework assists in objective prioritization of species and areas, based on the current and future potential threat of invasion. This means planning is based on invasiveness rather than on frequently used criteria such as resources, funding, and logistical considerations. Second, separating the area- and species-led approaches is often based on managerial bias, experience, and knowledge of species and systems because the approaches are seen as mutually exclusive. We see the two aspects as complementary and integrated. Finally, the framework guides the assessment of management priorities in a logical and structured way and provides insights into the problems and solutions of managing alien plant invasions in a large landscape in a clear, meaningful manner.

\section{Acknowledgments}

We thank L. Henderson and the Agricultural Research Council (Plant Protection Research Institute, Weeds Division) for providing the data from the SAPIA database and S. Mac Fadyen for GIS assistance. L.F. thanks D. and S. Nel and SANBI for financial support. L.F. and D.M.R. thank the DST-NRF Centre of Excellence for Invasion Biology for financial support.

\section{Literature Cited}

Alston, K. P., and D. M. Richardson. 2006. The roles of habitat features, disturbance, and distance from putative source populations in structuring alien plant invasions at the urban/wildland interface on the Cape Peninsula, South Africa. Biological Conservation 132:183-198.

Daehler, C. C., and D. A. Carino. 2000. Predicting invasive plants: prospects for a general screening system based on current regional models. Biological Invasions 2:93-102. 
DoC (Department of Conservation). 2000. The standard operating procedure for monitoring weed control. QD code: NH 1234. Department of Conservation, Te Papa Atawhai, New Zealand.

Foxcroft, L. C. 2001. A case study of human dimensions in invasion and control of alien plants in the personnel villages of Kruger National Park. Pages 127-134 in J. A. McNeely, editor. The great reshuffling: human dimensions of invasive alien species. World Conservation Union, Gland, Switzerland.

Foxcroft, L. C., and D. M. Richardson. 2003. Managing alien plant invasions in the Kruger National Park, South Africa. Pages 385-404 in L. E. Child, J. H. Brock, G. Brundu, K. Prach, P. Pysek, P. M. Wade, and M. Williamson, editors. Plant invasions: ecological threats and management solutions. Backhuys Publishers, Leiden, The Netherlands.

Foxcroft, L. C., L. Henderson, G. R. Nichols, and B. W. Martin. 2003. A revised list of alien plants for the Kruger National Park. Koedoe 46:21-44.

Foxcroft, L. C., M. Rouget, D. M. Richardson, and S. MacFadyen. 2004. Reconstructing 50 years of Opuntia stricta invasion in the Kruger National Park, South Africa: environmental determinants and propagule pressure. Diversity and Distributions 10:427437.

Freitag-Ronaldson, S., and L. C. Foxcroft. 2003. Anthropogenic influences at the ecosystem level. Pages 391-421 in J. T. Du Toit, K. H. Rogers, and H. C. Biggs, editors. The Kruger experience, ecology and management of savanna heterogeneity. Island Press, Washington, D.C.

Gelbard, J. L., and S. Harrison. 2003. Roadless habitats as refuges for native grasslands: interactions with soil, aspect, and grazing. Ecological Applications 13:404-415.

Gertenbach, W. P. D. 1983. Landscapes of the Kruger National Park. Koedoe 26:9-121.

Guisan, A., and W. Thuiller. 2005. Predicting species distribution: offering more than simple habitat models. Ecology Letters 8:993-1009.

Henderson, L. 1998. Southern African plant invaders atlas (SAPIA). Applied Plant Science 12:31-32.

Henderson, L. 1999. The Southern African plant invaders atlas (SAPIA) and its contribution to biological weed control. African Entomology Memoir 1:159-163.

Henderson, L. 2001. Alien weeds and invasive plants: a complete guide to declared weeds and invaders in South Africa. Handbook 12. Agricultural Research Council- Plant Protection Research Institute, Pretoria, South Africa.

Jiminez-Valverde, A., and J. M. Lobo. 2006. The ghost of unbalanced species distribution data in geographic model predictions. Diversity and Distributions 12:521-524.
KNP (Kruger National Park). 2006. Management plan for the Kruger National Park-objectives hierarchy. Pages 69-76 in S. FreitagRonaldson, editor. South African National Parks, Skukuza, South Africa.

Lonsdale, W. M., and A. M. Lane. 1994. Tourist vehicles as vectors of weed seeds in Kakado National Park, Northern Australia. Biological Conservation 69:277-283.

Nel, J. L., D. M. Richardson, M. Rouget, T. N. Mgidi, N. Mdzeke, D. C. Le Maitre, B. W. van Wilgen, L. Schonegevel, L. Henderson, and S. Neser. 2004. A proposed classification of invasive alien plant species in South Africa: towards prioritising species and areas for management action. South African Journal of Science 100:53-64.

Pheloung, P. C., P. A. Williams, and S. R. Halloy. 1999. A weed risk assessment model for use as a biosecurity tool evaluating plant introductions. Journal of Environmental Management 57:239-251.

Pollard, S., C. Shackleton, and J. Curruthers. 2003. Beyond the fence: people and the lowveld landscape. Pages 422-446 in J. T. Du Toit, K. H. Rogers, and H. C. Biggs, editors. The Kruger experience, ecology and management of savanna heterogeneity. Island Press, Washington, D.C.

Pyšek, P., and K. Prach. 1994. How important are rivers for supporting plant invasions? Pages 19-26 in L. C. de Waal, L. E. Child, P. M. Wade, and J. H. Brock, editors. Ecology and management of invasive riverside plants. John Wiley \& Sons, New York.

Richardson, D. M., P. Pyšek, M. Rejmánek, M. G. Barbour, F. D. Panetta, and C. West. 2000. Naturalization and invasion of alien plants: concepts and definitions. Diversity and Distributions 6:93-107.

Richardson, D. M., M. Rouget, S. J. Ralston, R. M. Cowling, B. J. van Rensburg, and W. Thuiller. 2005. Species richness of alien plants in South Africa: environmental correlates and the relationship with indigenous plant species richness. Ecoscience 12:391-402.

Rouget, M., D. M. Richardson, J. L. Nel, D. C. Le Maitre, B. Egoh, and T. N. Mgidi. 2004. Mapping the potential ranges of major plant invaders in South Africa, Lesotho and Swaziland using climatic suitability. Diversity and Distribution 10:475-484.

Thuiller, W. 2003. BIOMOD-optimizing predictions of species distributions and projecting potential future shifts under global change. Global Change Biology 9:1353-1362.

Tucker, K. C., and D. M. Richardson. 1995. An expert system for screening potentially invasive alien plants in South African fynbos. Journal of Environmental Management 44:309-338.

van Wilgen, B. W., J. L. Nel, and M. Rouget. 2007. Invasive alien plants and South African rivers: a proposed approach to the prioritization of control operations. Freshwater Biology: DOI:10.1111/J.13652427.2006.01711.x.

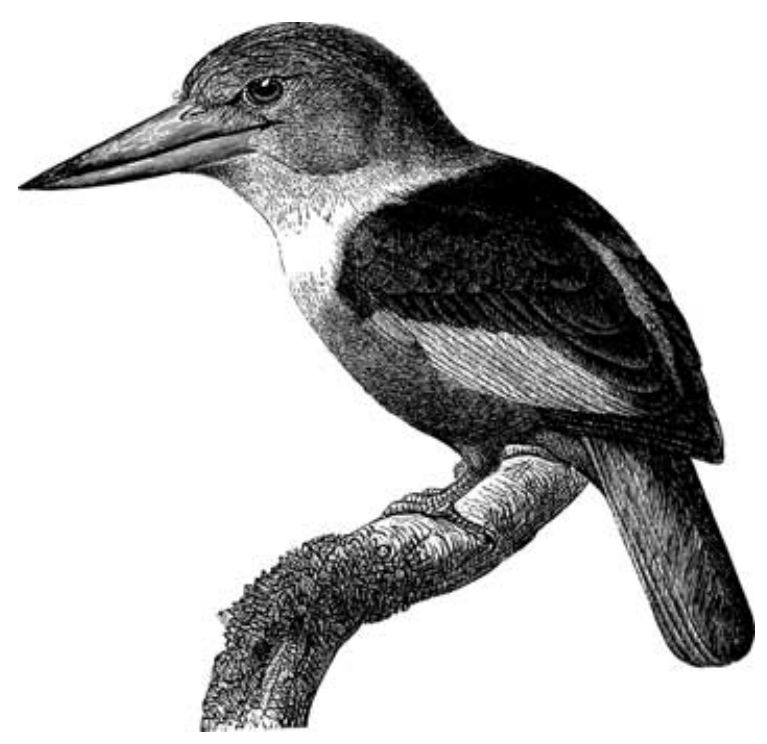

